Sylwia Firyn

Uniwersytet Gdański

sylwia.firyn@outlook.pl

\title{
ASPEKTY TLUMACZENIA NEOLOGIZMÓW NIEMIECKICH Z KOŃCA XX WIEKU NA JĘZYK POLSKI
}

DOl: http://dx.doi.org/10.12775/RP.2018.002

\begin{abstract}
Zarys treści: Artykuł prezentuje efekty badań na tłumaczeniami neologizmów niemieckich z ostatniego dziesięciolecia XX wieku na język polski. Zanalizowano 42 leksemy, które podzielono na leksemy odnoszące się do obszaru większego niż obszar Niemiec oraz leksemy nazywające zjawiska typowo niemieckie. Tłumaczenie drugiej grupy okazało się trudniejsze z powodu problemów z uwzględnieniem cech stylistycznych, szczególnie zaś ewaluatywnych. Autorka omawia krytycznie tłumaczenia tychże neologizmów w słownikach niemiecko-polskich i proponuje własne polskie odpowiedniki.
\end{abstract}

Słowa kluczowe: zapożyczenia, germanizmy, współczesny język polski

\section{0 neologizmach}

Neologizmy, czyli innowacje językowe, to nowe leksykalne, morfologiczne lub składniowe elementy języka (zob. Schippan 1992: 243-247). Można je podzielić na (zob. Grabias 1981 i 2003; Smółkowa 2001):

- neologizmy słowotwórcze (tutaj derywaty, skróty i skrótowce, zbitki wyrazowe itd.), np. falandyzacja, kuroniówka, dresiarz, netykieta, peowiec, PFRON,

- neologizmy znaczeniowe, czyli neosemantyzmy (istniejący wyraz otrzymuje nowe znaczenie), np. złoto, srebro, brąz ('złoty medal', 'srebrny medal', 'brązowy medal'), fura, 
- neologizmy stylistyczne/artystyczne (utworzone przez pisarza/poetę w dziełach literackich, np. zmalinić, śliworele, babcia od Azorka,

- neologizmy frazeologiczne (nowe kombinacje wyrazów), np. środki finansowe, dusić inflację, pójść na kuroniówkę, gwiezdny wóz, zwis męski.

Oprócz tego wyróżnić można neologizmy języka młodzieżowego, języka dzieci, medialne i obiegowe. Należy jednak stwierdzić, że proponowane przez badaczy polskich podziały są niehomogeniczne, gdyż bazują na różnych kryteriach $\mathrm{w}$ ramach tego samego podziału. Neologizmy stylistyczne lub medialne są często zarazem neologizmami słowotwórczymi. Dlatego w naszych rozważaniach nawiązujemy do podziałów niemieckich. Ponieważ celem naszych badań nie jest prezentowanie sposobów tłumaczeń z rozróżnieniem na typy neologizmów, niniejszy tekst nie zawiera szerokiej dyskusji na temat ich podziału. Taka rozbudowana dyskusja nie jest możliwa ze względu na ograniczoną objętość tej rozprawy.

Obiektem naszych rozważań są neologizmy leksykalne, czyli nowe wyrazy utworzone dla nazwania nowych przedmiotów i zjawisk. Mogą one pozostać okazjonalizmami lub wejść do języka standardowego. Pojawiają się w przypadku:

- konieczności nazwania nowego zjawiska/obiektu: Eierköpfer - obcinacz/gilotyna do jajek,

- konieczności nowej specyfikacji na płaszczyźnie denotatywnej (np. inne asocjacje oparte na nieco innym znaczeniu denotatywnym):

Politesse/Polizeihostess - strażniczka miejska (w odróżnieniu od Polizistin - policjantka),

- konieczności nowego wartościowania (nowe cechy ewaluacyjne): Ossi - określenie Niemców pochodzących z dawnej NRD, Wessi - określenie Niemców pochodzących z dawnej RFN, der Womanizer $=$ der Frauenheld $($ anglicyzm),

- potrzeby skrócenia dawnej długiej nazwy: sitt für nicht (mehr) durstig sein/keinen Durst (mehr) haben - nie mieć pragnienia.

Ze względu na pochodzenie neologizmy dzielą się na zapożyczenia ( $w$ ostatnich dziesięcioleciach głównie $\mathrm{z}$ języka angielskiego) oraz leksemy rodzime. Zapożyczenia $\mathrm{z}$ języka angielskiego to $\mathrm{w}$ zdecydowanej większości zapożyczenia leksykalne, zwane też właściwymi; rzadziej natomiast są to zapożyczenia treściowe, gdzie zapożyczona treść oddawana jest za pomocą morfemów/wyrazów języka rodzimego (por. Bußmann 1990: 215). W pierwszym przypadku chodzi więc o wyraz obcy niezasymilowany (np. iPod nano, 
iPhone 6, lycra, O.K., happy end, lifting) lub zasymilowanym, przy czym asymilacja dotyczyć może pisowni (strona graficzna), wymowy (asymilacja na płaszczyźnie fonetycznej), kategorii gramatycznych (fleksja, rodzaj gramatyczny) itd. (por. Biadun-Grabarek 1988):

a) asymilacja graficzna: dżinsy, dżersej,

b) asymilacja fonetyczna i graficzna: skaner, komputer, keczup, aerobik,

c) asymilacja tylko fonetyczna: marker, musical, spam,

d) asymilacja w ramach kategorii gramatycznych, np. fleksji: bazooka bazooki, dubbing - dubbingu.

W przypadku zapożyczeń treściowych, zwanych też ukrytymi lub semantycznymi, jest kilka możliwości (por. Bußmann 1990: 213 i n.). Przede wszystkim należy tutaj wyróżnić sytuację, w której pole znaczeniowe istniejącego słowa zostaje rozszerzone pod wpływem języka obcego (por. wikipedia. org/zapożyczenia), np.

mysz - nazwa gatunku zwierzęcia została rozszerzona o znaczenie „mysz komputerowa",

ikona - nazwa obrazu została rozszerzona o komputerowy znak graficzny symbolizujący plik lub folder.

Taki neologizm nazywany jest $\mathrm{w}$ literaturze polonistycznej neosemantyzmem lub nowoznacznikiem, w języku niemieckim - Lehnbedeutung, a $\mathrm{w}$ angielskim - semantic loan:

ang. icon $\rightarrow$ niem. Icon (nowe słowo) $\rightarrow$ pol. ikona (rozszerzenie treści istniejącego słowa).

Możemy też mieć z sytuację, w której powstaje w języku docelowym nowy wyraz (niem. Lehnbildung). Tu pojawiają się dwie możliwości, przy czym druga z nich ma dwa warianty (por. Grabarek 1986):

- tłumaczenie o całkowicie innej strukturze (niem. Lehnschöpfung), np. burnout $\rightarrow$ syndrom wypalenia zawodowego,

- tłumaczenie z częściowym lub całkowitym zachowaniem struktury i treści wyrazu z języka wyjściowego (niem. Lehnformung),

a) tłumaczenie $z$ częściowym zachowaniem struktury/treści języka wyjściowego (niem. Lehnübertragung), np. sky scraper $\rightarrow$ drapacz chmur (pośrednik niemieckie Wolkenkratzer),

b) tłumaczenie $\mathrm{z}$ całkowitym zachowaniem struktury i treści języka wyjściowego (niem. Lehnübersetzung; pol. kalka językowa, odbitka językowa), np. ang. road map $\rightarrow$ pol. mapa drogowa (niem. Roadmap jest zapożyczeniem leksykalnym), ang. Eastern enlargement $\rightarrow$ niem. Osterweiterung $\rightarrow$ pol. rozszerzenie na wschód. 
Powstanie neologizmów rodzimych jest skutkiem pojawiania się nowych zjawisk, specyficznych dla danego obszaru językowego, w pierwszej kolejności związanych z życiem codziennym i zjawiskami życia politycznego, np. Ostidentität, Ostalgie, Westalgie, ostalgisch, westalgisch.

Zarówno w przypadku zapożyczeń leksykalnych, jak i semantycznych przejęte może być całe znaczenie:

ang. burnout $\rightarrow$ niem. Burnout $\rightarrow$ pol. burnout,

ang. Eastern enlargement $\rightarrow$ niem. Osterweiterung - pol. rozszerzenie na wschód (NATO 1997),

ang. all-time high $\rightarrow$ niem. Allzeithoch, Höchstkurs, Rekordhöhe, Höchstwert, Höchststand $\rightarrow$ pol. rekordowa cena (akcji) wszech czasów,

lub tylko jego część:

ang. burnout $\rightarrow$ niem. Burnout $\rightarrow$ pol. burnout.

Do tego samego języka docelowego może trafić zarówno zapożyczenie leksykalne, jak i semantyczne:

ang. burnout $\rightarrow$ niem. Burnout, Burnout-Syndrom, Ausgebranntsein $\rightarrow$ pol. (syndrom) burnout, syndrom wypalenia zawodowego, wypalenie zawodowe,

ale może się zdarzyć tak, że w różnych językach pojawiają się nieco inne odpowiedniki:

ang. political correctness $\rightarrow$ niem. Political Correctness i Politische Korrektheit $\rightarrow$ pol. poprawność polityczna.

Stosunkowo nowym zjawiskiem są częste hybryd:

ang. basecap $\rightarrow$ niem. Baseballkappe $\rightarrow$ pol. bejsbolówka, ciucholand, zeszrotować itd.

Jeśli chodzi o wyrazy przejmowane $\mathrm{z}$ języka angielskiego w drugiej połowie XX wieku, to do języka niemieckiego trafiały w zasadzie tylko zapożyczenia bezpośrednie, a w przypadku polszczyzny zdarzało się, że uczestniczył w tym język pośredni:

eng. sky scraper $\rightarrow$ niem. Wolkenkratzer $\rightarrow$ pol. drapacz chmur.

\section{Znaczenie leksemu}

W badaniach synchronicznych na znaczenie wyrazu, oprócz znaczenia denotatywnego, czyli nazywającego, składają się jeszcze przynajmniej elementy ewaluatywne, stylistyczne i konotatywne (por. Conrad 1985: 40). Trzy ostatnie płaszczyzny wyrażane są często implicite. Do tego należy dodać nienazwane explicite elementy znaczenia denotatywnego oraz od- 
niesienie arealne, czyli regionalizmy. Wszystkie te elementy należałoby teoretycznie uwzględnić przy przekładzie neologizmu niemieckiego na język polski. Niestety nie zawsze jest to wykonalne. W niektórych przypadkach oddanie charakteru regionalnego/dialektalnego bez opisowego wyjaśnienia:

Grüß Gott! $\rightarrow$ Dzień dobry / Cześć / Szczęść Boże powiedział po bawarsku / w dialekcie bawarskim.

Dość łatwy do rozwiązania w procesie tłumaczenia jest problem wyrażonego explicite znaczenia denotatywnego. Tłumacz musi próbować tak oddać termin obcojęzyczny, by jego odpowiednik był właściwie rozumiany przez odbiorcę teksu docelowego. Najczęściej odbywa się to przez rozszerzenie informacji ukrytej o jawną. $Z$ drugiej strony zredukowane mogą być jawne elementy oczywiste dla odbiorcy tłumaczonego tekstu:

Frank-Walter Steinmeier traf den polnischen Außenminister Witold Waszczykowski - Minister spraw zagranicznych RFN Frank-Walter Steinmeier spotkat się z Witoldem Waszczykowskim.

Dodatkowe informacje mogą być umieszczone w nawiasie jako wyjaśnienie uzupełniające, zob. WSNP:

Ostalgie - ostalgia (tęsknota za czasami NRD).

Oprócz znaczenia denotatywnego należałoby przy tłumaczeniu haseł słownikowych uwzględnić następujące aspekty:

- wskazanie na fakt, że hasło pochodzi z płaszczyzny języka potocznego (j. potoczny),

- wskazanie na charakter wartościujący, a więc aspekty ewaluatywne (np. pozytywny, negatywny),

- informacje o aspektach stylistycznych (np. wulgarny, ironiczny).

\section{Korpus}

W części empirycznej uwzględniono wstępnie 42 leksemy, przy czym jako oddzielne hasła omówiono synonimy, gdyż w słowniku mogą być odrębnymi hasłami. Z kilkuset leksemów, które trafiły do języka niemieckiego w ostatnim dziesięcioleciu XX wieku, czyli w pierwszych dziesięciu latach po powstaniu zjednoczonych Niemiec, wybrane zostały głównie te, które odnoszą się do życia codziennego, ponieważ właśnie takie słowa sprawiają tłumaczom duże problemy i często są pomijane w słownikach dwujęzycznych. Leksemy te charakteryzują się częstym występowaniem w tekstach internetowych i innych mediów (telewizja, radio, prasa). 
Kolejna grupa leksemów to nazwy zjawisk politycznych. Zdecydowana większość opisywanych przykładów pochodzi ze słownika Neuer Wortschatz 2004. W słowniku tym nie zostały uwzględnione pewne neologizmy, najprawdopodobniej z powodu ich niepoprawności politycznej. Około $60 \%$ wynotowanych haseł nie występuje w DUW, co może być spowodowane między innymi dwiema przyczynami:

- niewejściem danego słowa do języka standardowego,

- niepoprawnością polityczną danego wyrazu.

Żaden z tych leksemów nie jest opisany w DWDS jako oddzielne hasło, ale wszystkie uwzględnione są w korpusie. W WSNP pojawia się sześć, a w PONS pięć tłumaczeń na język polski.

Wybrane neologizmy dzielimy na dwie grupy:

- odnoszące się do zjawisk znanych także poza obszarem niemieckojęzycznym, np. Osterweiterung, Einheitswährung, Doppelstaatler, Spartenkanal,

- odnoszące się do zjawisk występujących tylko na obszarze niemieckojęzycznym, np. Buschzulage, Jammerossi, Besserwessi, Zoni.

W przypadku pierwszej grupy odpowiedniki nazw niemieckich istnieją często w języku polskim jako określenia zleksykalizowane lub przynajmniej okazjonalne, co w grupie drugiej jest rzadkością. Wobec braku polskiego odpowiednika autor słownika dwujęzycznego ma trzy wyjścia:

1. Zastosować słowo obce (zapożyczenie leksykalne) z ewentualnym wyjaśnieniem w nawiasie (zob. wyżej Ostalgie).

2. Użyć jako odpowiednika istniejącego $\mathrm{w}$ języku docelowym słowa o zbliżonym znaczeniu, co jest jednak niebezpieczne, gdyż może skutkować przynajmniej częściową zmianą znaczenia oraz spowodować choćby polonizację w przypadku tłumaczenia tekstu $\mathrm{z}$ tym słowem (np. Erste Nationen - indianie (kanadyjscy); Neudeutsch nowomowa niemiecka; Auszeit - przerwa).Pojawiają się tutaj duże problemy z żeńskimi nazwami zawodów (mocja), które w języku niemieckim są $\mathrm{w}$ zasadzie ogólnie obowiązujące, natomiast $\mathrm{w}$ polskim tylko w wypadku zawodów tradycyjnych. Stosuje się więc nazwy męskie w rodzaju żeńskim (np. Bundeskanzlerin - kanclerz federalna; Ministerin - (ta) minister). Użycie nazw żeńskich jest czasem niemożliwe ze względu na istnienie już takich form dla innych zawodów, np. Professorin - profesorka (w liceum, a nie w szkole wyższej).

3. Próbować przetłumaczyć dane słowo z zachowaniem jego treści, stylistyki i ewaluacji, np. Ossi - Niemiec pochodzacy $z$ byłej NRD, wschodniak. 


\section{Metoda opisu}

Opis składa się z trzech części:

- listy wybranych leksemów ze wskazaniem na ich pojawianie się w słownikach języka niemieckiego, na niemieckojęzycznych stronach internetowych (skrót: Internet) oraz w największych słownikach niemiecko-polskich,

- opisu wybranych neologizmów będących nazwami zjawisk odnoszących się nie tylko do obszaru Niemiec/niemieckojęzycznego oraz propozycje ich tłumaczenia,

- opisu słów odnoszących się tylko do zjawisk na terenie Niemiec/niemieckojęzycznym, z ich charakterystyką ewaluacyjną, opisem werbalnym oraz propozycjami tłumaczenia.

Opis obejmuje:

- informację o występowaniu danych neologizmów w słownikach,

- znaczenie hasła,

- propozycję tłumaczenia na język polski.

Ponieważ neologizmy odnoszące się nie tylko do zjawisk obszaru niemieckojęzycznego często mają odpowiedniki polskie, większość rozważań poświęcona jest nazwom zjawisk na obszarze niemieckojęzycznym.

\section{Lista wybranych leksemów}

Poniższa lista leksemów zawiera informacje o ich występowaniu w słownikach niemieckich oraz dwóch największych aktualnych słownikach niemiecko-polskich.

\begin{tabular}{|l|c|c|c|c|c|c|}
\hline \multicolumn{1}{|c|}{ Leksem } & NW & Internet & DUW & DWDS & WSNP & PONS \\
\hline Abschübling & + & + & - & $-/+$ & - & - \\
\hline Besserwessi & + & + & + & $-/+$ & - & - \\
\hline Bundi & - & - & - & $-/+$ & - & - \\
\hline Buschzulage & + & + & - & $-/+$ & - & - \\
\hline Dezemberfieber & + & + & - & $-/+$ & - & - \\
\hline Doppelstaatler & + & + & + & $-/+$ & - & - \\
\hline Doppelstaater & $-/+{ }^{1)}$ & + & + & $-/+$ & - & - \\
\hline
\end{tabular}




\begin{tabular}{|c|c|c|c|c|c|c|}
\hline Leksem & NW & Internet & DUW & DWDS & WSNP & PONS \\
\hline Einheitswährung & + & + & + & $-/+$ & - & - \\
\hline Expressabitur & + & + & - & - & - & - \\
\hline Hingucker & + & + & + & $-1+$ & - & - \\
\hline Jammerossi & + & + & - & $-1+$ & - & - \\
\hline multikulti & + & + & + & $-1+$ & + & - \\
\hline Multikulti & + & + & + & $-1+$ & - & - \\
\hline Neufünfland & + & + & - & $-1+$ & - & - \\
\hline Opferakte & + & + & - & $-1+$ & - & - \\
\hline Ossi & $-1+$ & + & + & $-1+$ & + & + \\
\hline ostalgisch & + & + & + & $-1+$ & - & - \\
\hline Ostalgie & + & + & + & $-1+$ & + & - \\
\hline Osterweiterung & + & + & + & $-1+$ & - & + \\
\hline Ostidentität & + & + & - & $-1+$ & - & - \\
\hline ostig & + & + & - & $-1+$ & - & - \\
\hline Parlamentsfernsehen & - & + & + & $-1+$ & - & - \\
\hline Parlamentskanal & + & + & - & $-1+$ & - & - \\
\hline Passivhaus & + & + & + & $-1+$ & - & - \\
\hline Schleierfahndung & + & + & + & $-1+$ & - & - \\
\hline Schnellabitur & + & + & + & $-1+$ & - & - \\
\hline schönrechnen & + & + & + & $-1+$ & + & - \\
\hline Schübling & + & + & - & $-1+$ & - & - \\
\hline Solidaritätszuschlag & + & + & + & $-1+$ & + & + \\
\hline Solidarzuschlag & + & + & + & $-1+$ & - & - \\
\hline Solizuschlag & + & + & - & $-1+$ & - & - \\
\hline Spartenfernsehen & - & + & - & $-1+$ & - & - \\
\hline Spartenkanal & + & + & - & $-1+$ & - & - \\
\hline Spartensender & + & + & + & $-1+$ & + & - \\
\hline Superzahl & + & + & - & $-1+$ & - & - \\
\hline Turboabitur & + & + & - & $-1+$ & - & - \\
\hline Wessi & $-1+$ & + & + & $-1+$ & + & + \\
\hline
\end{tabular}




\begin{tabular}{|l|c|c|c|c|c|c|}
\hline \multicolumn{1}{|c|}{ Leksem } & NW & Internet & DUW & DWDS & WSNP & PONS \\
\hline Westalgie & + & + & - & $-/+$ & - & - \\
\hline westalgisch & - & + & - & - & - & - \\
\hline Wiedereinrichter & + & + & - & $-/+$ & - & - \\
\hline Wossi & + & + & - & $-/+$ & - & - \\
\hline Zoni & - & + & - & $-/+$ & - & - \\
\hline
\end{tabular}

1) Pojawia się w haśle Doppelstaatler.

2) Pojawia się w haśle Jammerossi.

3) Pojawia się w haśle Besserwessi.

Wyjaśnienia znaków:

+ jest hasło

- brak hasła

-/+ brak hasła, ale jest w korpusie DWDS lub w innym haśle w NW

\section{Tłumaczenie leksemów odnoszących się nie tylko do obszaru niemiec- kojęzycznego}

W przypadku nazw zjawisk odnoszących się nie tylko do obszaru niemieckojęzycznego nie ma poważniejszych trudności z ich tłumaczeniem, bo większość ich odpowiedników istnieje też w języku polskim i jest w nim używana.

\begin{tabular}{|l|l|l|}
\hline \multicolumn{1}{|c|}{ Leksem } & \multicolumn{1}{|c|}{ Wyjaśnienie znaczenia } & \multicolumn{1}{c|}{ Propozycja tłumaczenia } \\
\hline Abschübling & $\begin{array}{l}\text { cudzoziemiec, który ma być } \\
\text { deportowany w związku z od- } \\
\text { rzuceniem wniosku o azyl }\end{array}$ & $\begin{array}{l}\text { osoba (przeznaczona) do } \\
\text { deportacji, } \\
\text { osoba w areszcie deportacyj- } \\
\text { nym, osoba z nakazem opusz- } \\
\text { czenia kraju }\end{array}$ \\
\hline Dezemberfieber & $\begin{array}{l}\text { takie zarządzanie finansami } \\
\text { firm, instytucji, które zmierza } \\
\text { do wydania wszystkich przewi- } \\
\text { dzianych na dany rok pieniędzy, } \\
\text { by utrzymać wysokość finanso- } \\
\text { wania w następnym roku }\end{array}$ & $\begin{array}{l}\text { grudniowa gorączka finansowa } \\
\text { w firmach) }\end{array}$ \\
\hline Doppelstaatler & $\begin{array}{l}\text { człowiek, który ma dwie przy- } \\
\text { należności państwowe }\end{array}$ & dwupaństwowiec \\
\hline Doppelstaater & $\begin{array}{l}\text { człowiek, który ma dwie przy- } \\
\text { należności państwowe }\end{array}$ & dwupaństwowiec \\
\hline
\end{tabular}




\begin{tabular}{|c|c|c|}
\hline Leksem & Wyjaśnienie znaczenia & Propozycja tłumaczenia \\
\hline Einheitswährung & $\begin{array}{l}\text { wspólna waluta w grupie } \\
\text { państw }\end{array}$ & $\begin{array}{l}\text { wspólna waluta, jednolita } \\
\text { waluta }\end{array}$ \\
\hline Hingucker & $\begin{array}{l}\text { osoba lub przedmiot przyciąga- } \\
\text { jące wzrok/uwagę }\end{array}$ & przyciągacz uwagi/wzroku \\
\hline multikulti & $\begin{array}{l}\text { łączący w sobie więcej niż jedną } \\
\text { kulturę }\end{array}$ & wielokulturowy, multikulti \\
\hline Multikulti & $\begin{array}{l}\text { osoba żyjąca na pograniczu } \\
\text { wielu kultur i łącząca je w swo- } \\
\text { im życiu }\end{array}$ & wielokulturowiec, multikulti \\
\hline Opferakte & $\begin{array}{l}\text { dokumentacja osoby inwi- } \\
\text { gilowanej przez enerdowską } \\
\text { bezpiekę }\end{array}$ & $\begin{array}{l}\text { akta/teczka osoby inwigilowa- } \\
\text { nej }\end{array}$ \\
\hline Osterweiterung & $\begin{array}{l}\text { rozszerzenie NATO, a później } \\
\text { UE na wschód }\end{array}$ & $\begin{array}{l}\text { zaproponowe w PONS „rozsze- } \\
\text { rzenie na Wschód”, dodać tylko } \\
\text { można NATO lub UE }\end{array}$ \\
\hline Parlamentsfernsehen & $\begin{array}{l}\text { telewizja / stacja telewizyjna } \\
\text { transmitująca obrady parla- } \\
\text { mentu }\end{array}$ & $\begin{array}{l}\text { stacja telewizyjna transmitująca } \\
\text { obrady parlementu }\end{array}$ \\
\hline Parlamentskanal & $\begin{array}{l}\text { tematyczny kanał telewizyjny } \\
\text { transmitujący obrady parla- } \\
\text { mentu }\end{array}$ & $\begin{array}{l}\text { (tematyczny) kanał telewizyjny } \\
\text { transmitujący obrady parla- } \\
\text { mentu, ew. telewizja parlamen- } \\
\text { tarna }\end{array}$ \\
\hline Passivhaus & \begin{tabular}{|l|} 
zbudowany według zasad \\
ekologicznych budynek bez \\
konwencjonalnego ogrzewania, \\
dobrze izolowany
\end{tabular} & $\begin{array}{l}\text { dom pasywny (zob.. Encyklo- } \\
\text { pedia PWN), dom ekologiczny }\end{array}$ \\
\hline Schleierfahndung & $\begin{array}{l}\text { policyjna kontrola / policyjne } \\
\text { poszukiwanie bez konkretnej } \\
\text { przyczyny }\end{array}$ & $\begin{array}{l}\text { kontrola policyjna bez konkret- } \\
\text { nej przyczyny }\end{array}$ \\
\hline schönrechnen & $\begin{array}{l}\text { wyliczać upiększająco, tak by } \\
\text { możliwa była dobra interpre- } \\
\text { tacja }\end{array}$ & robić wyliczenie upiększające \\
\hline Schübling & $\begin{array}{l}\text { cudzoziemiec, który ma być } \\
\text { deportowany w związku z od- } \\
\text { rzuceniem wniosku o azyl }\end{array}$ & $\begin{array}{l}\text { osoba do deportacji - osoba } \\
\text { w areszcie deportacyjnym }\end{array}$ \\
\hline Spartenfernsehen & $\begin{array}{l}\text { telewizja tematyczna/specjali- } \\
\text { styczna }\end{array}$ & $\begin{array}{l}\text { telewizja tematyczna/specjali- } \\
\text { styczna }\end{array}$ \\
\hline Spartenkanal & $\begin{array}{l}\text { telewizyjny kanał tematyczny/ } \\
\text { specjalistyczny }\end{array}$ & $\begin{array}{l}\text { kanał tematyczny/specjalisty- } \\
\text { czny }\end{array}$ \\
\hline Spartensender & stacja/telewizja tematyczna & stacja/telewizja tematyczna \\
\hline
\end{tabular}


W przypadku Multikulti i multikulti mamy w zasadzie do czynienia ze specyficznym terminem określającym sytuację w Niemczech. Są to specyficzne skróty od pojęć Multikulturalismus i multikulturell, które nazywają zjawiska o zasięgu ogólnoświatowym (por. wielokulturowy, wielokulturowość; ang. Multiculturalism/multicultural, franc. Multiculturalisme/multicultural, wł. Multiculturalismo/multiculturale).

Niektóre z wymienionych powyżej haseł można podzielić na podstawie opisów ich znaczenia w NW w grupy wyrazów bliskoznacznych:

a) Abschübling, Schübling;

b) Spartenfernsehen, Spartensender, Spartenkanal;

c) Doppelstaatler, Doppelstaater;

d) Parlamentsfernsehen, Parlamentskanal.

Istnienie dwóch lub nawet więcej nazw jest skutkiem nieustabilizowanej terminologii (Doppelstaatler, Doppelstaater) i niewielkich różnic znaczeniowych (Parlamentsfernsehen, Parlamentskanal - w pierwszym przypadku może to być jeden kanał telewizji wielokanałowej, a w drugim samodzielna stacja telewizyjna).

Synonimy mogą być oddawane w języku polskim przez jedno hasło (telewizja parlamentarna). Pojawia się tutaj też termin TVP Parlament, który odnosi się tylko do TVP.

W analizie grupy leksemów nazywających zjawiska specyficzne dla danego kraju opis składa się z czterech części:

1) hasło,

2) podana w szpalcie „charakterystyka” informacji:

- stylistyczno-ewaluatywnych, np. pejoratywny, ironiczny itd.,

- dotyczących odmiany języka, np. standardowy, potoczny,

3) szczegółowy opis znaczenia leksemu,

4) propozycja tłumaczenia na język polski.

\section{Propozycje tłumaczenia leksemów odnoszących się do zjawisk na terenie Niemiec}

Mamy tutaj do czynienia z leksemami określającymi to, co w języku niemieckim noszą nazwę „Landesspezifika”. 


\begin{tabular}{|c|c|c|c|}
\hline Leksem & $\begin{array}{c}\text { Charakterystyka } \\
\text { stylistyczna }\end{array}$ & Opis znaczenia & $\begin{array}{c}\text { Propozycja } \\
\text { tłumaczenia }\end{array}$ \\
\hline der/die Besserwessi & $\begin{array}{l}\text { ironicznie, negatyw- } \\
\text { nie, } \\
\text { język potoczny }\end{array}$ & $\begin{array}{l}\text { obywatel starej RFN, } \\
\text { którego zachowa- } \\
\text { nie jest uważane } \\
\text { za aroganckie, typ } \\
\text { przemądrzały; także } \\
\text { kobieta }\end{array}$ & $\begin{array}{l}\text { przemądrzały/ } \\
\text { arogancki zachod- } \\
\text { niak, przemądrzała/ } \\
\text { arogancka zachod- } \\
\text { niaczka }\end{array}$ \\
\hline der/die Bundi & $\begin{array}{l}\text { ironicznie, negatyw- } \\
\text { nie, } \\
\text { język potoczny }\end{array}$ & $\begin{array}{l}\text { pochodzący z dawnej } \\
\text { RFN mieszkaniec } \\
\text { wschodnich landów, } \\
\text { z lekkim zabarwie- } \\
\text { niem ironicznym }\end{array}$ & $\begin{array}{l}\text { federalniak (na } \\
\text { wschodzie) zachod- } \\
\text { niak (na wschodzie) }\end{array}$ \\
\hline $\begin{array}{l}\text { Buschzulage } \\
\text { synonimy: Busch- } \\
\text { prämie } \\
\text { Buschgeld }\end{array}$ & $\begin{array}{l}\text { ironicznie, } \\
\text { język potoczny }\end{array}$ & $\begin{array}{l}\text { dodatek dla miesz- } \\
\text { kańców starej RFN } \\
\text { podejmujących } \\
\text { pracę na terenie byłej } \\
\text { NRD po roku } 1990, \\
\text { w celu zachęcenia ich } \\
\text { do podjęcia pracy } \\
\text { w nowych krajach } \\
\text { związkowych }{ }^{1)}\end{array}$ & $\begin{array}{l}\text { buszowe, dodatek } \\
\text { buszowy, premia za } \\
\text { pracę w buszu }\end{array}$ \\
\hline das Expressabitur & $\begin{array}{l}\text { ironicznie, negatyw- } \\
\text { nie, } \\
\text { język potoczny }\end{array}$ & $\begin{array}{l}\text { matura zdawana po } \\
12 \text { zamiast po } 13 \\
\text { latach nauki }\end{array}$ & $\begin{array}{l}\text { przyspieszona } \\
\text { matura, } \\
\text { matura ekspresowa }\end{array}$ \\
\hline $\begin{array}{l}\text { der/die Jammerossi } \\
\text { synonim: Meckerossi }\end{array}$ & $\begin{array}{l}\text { ironicznie, negatyw- } \\
\text { nie, } \\
\text { język potoczny }\end{array}$ & $\begin{array}{l}\text { osoba ze wschodnich } \\
\text { landów, nieaktywna, } \\
\text { nieenergiczna, ale } \\
\text { ciągle narzekająca }\end{array}$ & $\begin{array}{l}\text { zrzęda ze wschodu } \\
\text { mękoła ze wschodu }\end{array}$ \\
\hline $\begin{array}{l}\text { das Neufünfland }{ }^{2} \\
\text { synonimy: } \\
\text { östliche/ostdeutsche/ } \\
\text { fünf neue Bundes- } \\
\text { länder }\end{array}$ & $\begin{array}{l}\text { ironicznie, negatyw- } \\
\text { nie, } \\
\text { język standardowy, } \\
\text { pogranicze do po- } \\
\text { tocznego }\end{array}$ & $\begin{array}{l}\text { obszar pięciu nowych } \\
\text { krajów związkowych } \\
\text { (obszar dawnej } \\
\text { NRD) }\end{array}$ & $\begin{array}{l}\text { pięć nowych krajów } \\
\text { związkowych, } \\
\text { kraje związkowe na } \\
\text { obszarze byłej NRD } \\
\text { (tutaj brak ironii) }\end{array}$ \\
\hline der/die Ossi & $\begin{array}{l}\text { ironicznie, negatyw- } \\
\text { nie, } \\
\text { język potoczny }\end{array}$ & $\begin{array}{l}\text { ironiczne, a na- } \\
\text { wet pejoratywne } \\
\text { określenie Niemca, } \\
\text { mieszkańca/miesz- } \\
\text { kanki nowych krajów } \\
\text { związkowych }\end{array}$ & $\begin{array}{l}\text { wschodniak/wschod- } \\
\text { niaczka }{ }^{3)}\end{array}$ \\
\hline die Ostalgie & $\begin{array}{l}\text { nieco ironicznie, } \\
\text { język standardowy }\end{array}$ & $\begin{array}{l}\text { tęsknota/nostalgie } \\
\text { za formami życia } \\
\text { w dawnej NRD, } \\
\text { dotyczy mieszkań- } \\
\text { ców nowych krajów } \\
\text { związkowych }\end{array}$ & $\begin{array}{l}\text { ostalgia, nostalgia za } \\
\text { życiem w } \text { NRD }^{4)}\end{array}$ \\
\hline ostalgisch & $\begin{array}{l}\text { nieco ironicznie, } \\
\text { język standardowy }\end{array}$ & $\begin{array}{l}\text { mający charakter } \\
\text { tęsknoty za formami } \\
\text { życia w byłej NRD }\end{array}$ & $\begin{array}{l}\text { ostalgiczny, nostal- } \\
\text { giczny za życiem } \\
\text { w NRD }{ }^{5}\end{array}$ \\
\hline
\end{tabular}




\begin{tabular}{|c|c|c|c|}
\hline Leksem & $\begin{array}{c}\text { Charakterystyka } \\
\text { stylistyczna }\end{array}$ & Opis znaczenia & $\begin{array}{c}\text { Propozycja } \\
\text { tłumaczenia }\end{array}$ \\
\hline die Ostidentität & $\begin{array}{l}\text { neutralnie, } \\
\text { język standardowy }\end{array}$ & $\begin{array}{l}\text { mentalne identyfiko- } \\
\text { wanie się miesz- } \\
\text { kańców byłej NRD } \\
\text { na podstawie ich } \\
\text { wcześniejszego życia }\end{array}$ & $\begin{array}{l}\text { tożsamość wschod- } \\
\text { nia/wschodniaków, } \\
\text { tożsamość mieszkań- } \\
\text { ców byłej NRD }\end{array}$ \\
\hline ostig & $\begin{array}{l}\text { negatywne, ironicz- } \\
\text { nie, } \\
\text { język potoczny }\end{array}$ & $\begin{array}{l}\text { określenie cech } \\
\text { mieszkańców byłej } \\
\text { NRD przez miesz- } \\
\text { kańców starej RFN }\end{array}$ & wschodniacki' \\
\hline die Schleierfahndung & $\begin{array}{l}\text { neutralnie, } \\
\text { język standardowy }\end{array}$ & $\begin{array}{l}\text { policyjna kontrola / } \\
\text { policyjne poszukiwa- } \\
\text { nie bez konkretnej } \\
\text { przyczyny }\end{array}$ & $\begin{array}{l}\text { kontrola policyjna } \\
\text { (bez konkretnej } \\
\text { przyczyny) }\end{array}$ \\
\hline das Schnellabitur & $\begin{array}{l}\text { neutralnie, } \mathrm{z} \text { tenden- } \\
\text { cją do ironii, nieco } \\
\text { negatywnie, } \\
\text { język standardowy }\end{array}$ & $\begin{array}{l}\text { matura zdawana po } \\
12 \text { zamiast po } 13 \\
\text { latach nauki }\end{array}$ & $\begin{array}{l}\text { przyspieszona } \\
\text { matura } \\
\text { skrócona droga do } \\
\text { matury }\end{array}$ \\
\hline $\begin{array}{l}\text { der Solidaritätszu- } \\
\text { schlag }\end{array}$ & $\begin{array}{l}\text { neutralnie, } \\
\text { język standardowy }\end{array}$ & $\begin{array}{l}\text { opłata / część } \\
\text { dochodów na rzecz } \\
\text { odbudowy wschod- } \\
\text { nich landów, swego } \\
\text { rodzaju podatek }\end{array}$ & $\begin{array}{l}\text { podatek solidarno- } \\
\text { ściowy }\end{array}$ \\
\hline der Solidarzuschlag & $\begin{array}{l}\text { neutralnie, } \\
\text { język standardowy, } \\
\text { skrócona forma } \\
\text { od „Solidaritätszu- } \\
\text { schlag” }\end{array}$ & $\begin{array}{l}\text { opłata / część } \\
\text { dochodów na rzecz } \\
\text { odbudowy wschod- } \\
\text { nich landów, swego } \\
\text { rodzaju podatek }\end{array}$ & $\begin{array}{l}\text { opłata solidarno- } \\
\text { ściowa / na rozwój } \\
\text { wschodnich landów }\end{array}$ \\
\hline der Solizuschlag & $\begin{array}{l}\text { neutralnie, } \\
\text { język standardowy, } \\
\text { skrócona forma } \\
\text { od „Solidaritätszu- } \\
\text { schlag” }\end{array}$ & $\begin{array}{l}\text { opłata / część } \\
\text { dochodów na rzecz } \\
\text { odbudowy wschod- } \\
\text { nich landów, swego } \\
\text { rodzaju podatek }\end{array}$ & $\begin{array}{l}\text { opłata solidarno- } \\
\text { ściowa / na rozwój } \\
\text { wschodnich landów }\end{array}$ \\
\hline die Superzahl & $\begin{array}{l}\text { neutralnie, } \\
\text { język standardowy }\end{array}$ & $\begin{array}{l}\text { ostatnia cyfra nume- } \\
\text { ru losu, podwyższa- } \\
\text { jąca wygraną }\end{array}$ & $\begin{array}{l}\text { supernumer, ostatnia } \\
\text { cyfra numeru ku- } \\
\text { ponu }\end{array}$ \\
\hline das Turboabitur & $\begin{array}{l}\text { ironicznie, negatyw- } \\
\text { nie, } \\
\text { język potoczny }\end{array}$ & $\begin{array}{l}\text { matura zdawana po } \\
12 \text { zamiast po } 13 \\
\text { latach nauki }\end{array}$ & $\begin{array}{l}\text { przyspieszona matu- } \\
\text { ra }^{8} \text { turbomatura }\end{array}$ \\
\hline der/die Wessi & $\begin{array}{l}\text { ironicznie, negatyw- } \\
\text { nie, } \\
\text { język potoczny }\end{array}$ & $\begin{array}{l}\text { wywodzący się } \\
\text { z obszaru byłej RFN } \\
\text { obywatel zjednoczo- } \\
\text { nych Niemiec, nazwa } \\
\text { używana zasadniczo } \\
\text { przez Niemców } \\
\text { wywodzących się } \\
\text { z NRD }\end{array}$ & zachodniak $^{9)}$ \\
\hline
\end{tabular}




\begin{tabular}{|c|c|c|c|}
\hline Leksem & $\begin{array}{l}\text { Charakterystyka } \\
\text { stylistyczna }\end{array}$ & Opis znaczenia & $\begin{array}{c}\text { Propozycja } \\
\text { tłumaczenia }\end{array}$ \\
\hline Westalgie & $\begin{array}{l}\text { neutralnie lub } \\
\text { ironicznie i pejora- } \\
\text { tywnie }{ }^{10)} \\
\text { język potoczny }\end{array}$ & $\begin{array}{l}\text { tęsknota/nostalgia } \\
\text { za formami życia } \\
\text { w dawnej RFN, } \\
\text { dotyczy mieszkań- } \\
\text { ców starych krajów } \\
\text { zwiazkowych }\end{array}$ & $\begin{array}{l}\text { nostalgia za sposo- } \\
\text { bem życia w starej } \\
\text { RFN, westalgia? }\end{array}$ \\
\hline westalgisch & $\begin{array}{l}\text { neutralnie lub } \\
\text { ironicznie i pejora- } \\
\text { tywnie } \\
\text { język potoczny }\end{array}$ & $\begin{array}{l}\text { mający charakter } \\
\text { tęsknoty/nostalgii } \\
\text { za formami życia } \\
\text { w starej RFN }\end{array}$ & $\begin{array}{l}\text { westalgiczny, odno- } \\
\text { szący się do tęsknoty, } \\
\text { nostalgii za sposo- } \\
\text { bem życia w starej } \\
\text { RFN }\end{array}$ \\
\hline Wiedereinrichter & $\begin{array}{l}\text { neutralnie z tenden- } \\
\text { cją do pozytywnie, } \\
\text { język standardowy }\end{array}$ & $\begin{array}{l}\text { rolnik przejmujący } \\
\text { do samodzielnej } \\
\text { uprawy ziemię odda- } \\
\text { ną w NRD rolniczej } \\
\text { spółdzielni produk- } \\
\text { cyjnej }\end{array}$ & $\begin{array}{l}\text { na nowo urządzający } \\
\text { się rolnik, noworol- } \\
\text { nik }\end{array}$ \\
\hline Wossi & $\begin{array}{l}\text { ironicznie, negatyw- } \\
\text { nie, } \\
\text { język potoczny }\end{array}$ & $\begin{array}{l}\text { wywodzący się } \\
\text { z obszaru byłej RFN } \\
\text { obywatel zjednoczo- } \\
\text { nych Niemiec }\end{array}$ & zachodniak \\
\hline Zoni & $\begin{array}{l}\text { ironicznie, negatyw- } \\
\text { nie, } \\
\text { język potoczny }\end{array}$ & $\begin{array}{l}\text { lekceważące, iro- } \\
\text { niczne nazywanie } \\
\text { Niemca pochodzą- } \\
\text { cego z byłej NRD, } \\
\text { odniesienie do } \\
\text { strefy radzieckiej, } \\
\text { NRD była nazywana } \\
\text { „Zone” lub „SBZ” }\end{array}$ & $\begin{array}{l}\text { wschodniak, strefo- } \\
\text { wiec (strefa radziec- } \\
\text { ka, NRD) }\end{array}$ \\
\hline
\end{tabular}

1) Celem było utworzenie nowej administracji, termin przejęty z czasów kolonialnych (Cesarstwo Niemieckie po roku 1880), wówczas bez negatywnej ewaluacji - dodatek dla urzędników i żołnierzy przebywających w koloniach.

2) Analogia do słowa Neufundland (Nowa Funlandia), wyraz utworzony z fünf neue Länder, derywaty Neufünfländer, neufünfländisch są praktycznie nieprzetłumaczalne na język polski.

3) Proponowane W PONS tłumaczenie enerdowiec jest nieekwiwalentne, bo tak nazywano w Polsce Niemca z NRD - negatywnie i ironicznie; proponowane w WSNP tłumaczenie mieszkaniec/mieszkanka byłej NRD jest treściowo lepsze, ale nie zawiera elementu ironii i nie jest w żadnym stopniu pejoratywne.

4) Propozycja w WSNP brzmi ostalgia, z wyjaśnieniem tęsknota za czasami NRD, jest w zasadzie udana; można też zaproponować tęsknota/nostalgia za sposobem życia $w$ byłej NRD.

5) Jeżeli przyjmiemy zapożyczenie leksykalne ostalgia, to można przyjąć też ostalgiczny, możliwe jest także tłumaczenie opisowe: odnoszący się do tęsknoty/nostalgii za sposobem życia w byłej NRD.

6) Słowo wschodniacki jest nacechowane negatywnie i należy do języka potocznego.

7) Tłumaczenie w PONS jako dodatek solidarnościowy jest błędne, gdyż jest to opłata solidarnościowa na rozwój wschodnich landów.

8) Oprócz stosunkowo neutralnego terminu w języku standardowym Schnellabitur, które odpowiada polskiemu terminowi przyspieszona matura, choć słowo polskie nie jest pełnym odpowiednikiem sło- 
wa niemieckiego, bo w Polsce egzamin może nastąpić już po roku nauki eksternistycznej. Dwa dalsze terminy, czyli Ekspressabitur i Turboabitur, należą języka potocznego i zawierają cechy ironiczny i negatywny. Stąd też propozycja polskich odpowiedników matura expresowa i turbomatura. Matura ekspresowa występuje na polskojęzycznych stronach internetowych. W niektórych tekstach występuje termin matura $w$ wersji turbo. W Austrii znane są nazwy Turbo-Matura i Matura Turbo. Słowa te są strefą przejściową między grupą poprzednią a tą. Mają one specyficzne niemieckie znaczenie i użycie, ale określenia takie znane są także poza Niemcami, choć w nie identycznym znaczeniu.

9) Zaproponowane w WSNP tłumaczenie mieszkaniec/mieszkanka byłej RFN oraz w PONS mieszkaniec/mieszkanka RFN przed zjednoczeniem Niemiec budzi wątpliwości, ponieważ Wessi jest obywatelem współczesnych Niemiec wywodzącym się ze starej RFN. W zaproponowanych tłumaczeniach brak też ironii i pejoratywności.

10) Przez Niemców ze starej RFN słowo traktowane jest neutralnie, a niektórzy nadają mu nawet cechę pozytywności; natomiast przez Niemców wywodzących z byłej NRD określenie interpretowane jest raczej jako ironiczne i pejoratywne. Istnieje określenie Westalgiker.

\section{Uwagi końcowe}

Badane neologizmy będące słowami niemieckimi zostały podzielone na dwie grupy: neologizmy dotyczące obszaru większego niż Niemcy i neologizmy odnoszące się do zjawisk specyficznie niemieckich. Potwierdziła się teza, że nie ma problemów z tłumaczeniem 19 pojęć zaliczonych do pierwszej grupy oraz leżącego na pograniczu terminu Schnellabitur. Ich odpowiedniki można znaleźć w słownikach bądź na stronach internetowych.

Leksemy z drugiej grupy należy podzielić ze względu na możliwość tłumaczenia na dwie podgrupy. Dla pierwszej z nich udało się z mniejszym lub większym trudem znaleźć polskie odpowiedniki, natomiast dla drugiejokazało się to prawie niemożliwe, a odpowiedniki polskie mają charakter warunkowy. Do ostatniej podgrupy należą takie leksemy jak: der/die Bundi, der/ die Zoni; die Ostalgie, ostalgisch, die Westalgie, westalgisch; das Expressabitur, das Turboabitur; das Neufünfland, die Schleierfahndung.

Leksemy der/die Bundi i der/die Zoni charakteryzują się w porównaniu z Wessi i Ossi większą dozą ironii i większą negatywnością. Nie udało się ich jednak przetłumaczyć inaczej niż za pomocą odpowiedników Wessi i Ossi, czyli jako zachodniak i wschodniak.

Podobnie jest w przypadku Expressabitur i Turboabitur, bo tu pojawia się trudność z oddaniem silnej ironii i dużej negatywności. Oprócz odpowiednika neutralnego (przyspieszona matura) można próbować tłumaczyć te słowa metodą kalki językowej, czyli matura ekspresowa, matura turbo, które to określenia pojawiają się na stronach internetowych w języku polskim.

Leksemy Ostalgie. ostalgisch, Westalgie i westalgisch można oddać przez zapożyczenia leksykalne bądź opisowo (skrócone definicje). 
Leksemy das Neufünfland i die Schleierfahndung dały się przetłumaczyć tylko opisowo (skrócone definicje).

Zaproponowano też inne tłumaczenie słów Wessi i Ossi niż to zawarte $\mathrm{w}$ istniejących słownikach niemiecko-polskich.

Podsumowując rozważania, należy stwierdzić, że można przetłumaczyć w zasadzie wszystkie neologizmy niemieckie na języka polski, stosując metody zaproponowane przez J. Grabarka (1986). Pojawiająca się w tym przypadku ekwiwalencja zerowa nie jest więc nieprzezwyciężalną barierą.

\section{Literatura}

al-Wadi, D., 2013, Zwergentechnologie, Alphamädchen, zurückleaken. Verdeckte neue Wörter des Neologismenwörterbuchs besser zugänglich machen, [w:] Sprachreport, nr 3, s. 16-24.

Biaduń-Grabarek, H., 1988, Zur graphematisch-phonologischen Assimilation des deutschen Wortschatzes an das polnische Sprachsystem, [w:] Wissenschaftliche Zeitschrift der PH Güstrow, nr 26, s. 53-60.

Bußmann, H., 1990, Lexikon der Sprachwissenschaft, wyd. 2, Stuttgart.

Conrad, R. (red.), 1985, Lexikon sprachwissenschaftlicher Termini, Leipzig.

Grabarek, J., 1986, Zur Auflösung der Nulläquivalenz im nominalen Bereich bei der Translation aus dem Deutschen ins Polnische, [w:] Studia Germanica Posnaniensia, nr 15, Poznań, s. 36-49.

Grabias, S., 1981, O ekspresywności języka: ekspresja a słowotwórstwo, Lublin. Grabias, S., 2003, Język w zachowaniach społecznych, Lublin.

Herberg, D., 2000, „Neologismen der Neunzigerjahre”, [w:] Neues und Fremdes im deutschen Wortschatz. Aktueller lexikalischer Wandel, G. Stickel (red.), Berlin - New York, s. 89-104.

Herberg, D., 2002, Kurzzeitwörter oder: Der atmende Wortschatz, [w:] Archaismen - Archaisierungsprozesse - Sprachdynamik, U. Kramer (red.), Frankfurt am Main, s. 11-24.

Herberg, D., 2002, Neologismen in der deutschen Gegenwartssprache. Probleme ihrer Erfassung und Beschreibung, [w:] Deutsch als Fremdsprache, nr 4, s. 125-200.

Schippan, Th., 1992, Lexikologie der deutschen Gegenwartssprache, Tübingen. Smółkowa, T., 2001, Neologizmy we współczesnej leksyce polskiej, Kraków.

Steffens, D., 2009, 20 Jahre Mauerfall-Zur Wortschatzentwicklung seit der Wendezeit, [w:] Deutsche Sprache, nr 2-3, s. 148-167.

Steffens, D., 2011, Wo ein Wille ist, ist auch ein Weg - Das erste größere Neo- 
logismenwörterbuch für das Deutsche, [w:] Deutsche und polnische Lexikographie nach 1945 im Spannungsfeld der Kulturgeschichte, L. Zieliński, K.-D. Ludwig, R. Lipczuk (red.), Frankfurt am Main, s. 69-80.

Steffens, D., al-Wadi, D., 2013, Neuer Wortschatz. Neologismen im Deutschen 1991-2010, t. 1-2, Mannheim.

Tellenbach, E., 2002, Neologismen der neunziger Jahre. Vom Textkorpus zur Datenbank, [w:] Das Wort im Text und Wörterbuch, I. Berz, U. Fix, G. Lerchner (red.), Leipzig, s. 105-118.

Welke, K., Sauer, W.W., Glück, H., 1992, Die deutsche Sprache nach der Wende, Hildesheim - New York.

\section{Jednojęzyczne słowniki niemieckie}

NW - Herberg, D., Kinne, M., Steffens, D., Tellenbach, E., Wadi, D., Neuer Wortschatz: Neologismen der 90er Jahre im Deutschen, Berlin 2004.

DUW - DUDEN: Deutsches Universalwörterbuch, wyd. 8, Berlin 2015.

DWDS - Digitales Wörterbuch der deutschen Sprache mit etymologischen Wörterbuch, Thesaurus, Wortprofil, Textkorpora, www.dwds.de (dostęp: 10 czerwca 2017 r.).

\section{Słowniki dwujęzyczne}

WSNP - Wielki słownik niemiecko-polski, J. Wiktorowicz, A. Frączek (red.), Warszawa 2010.

PONS - PONS Online-Wörterbuch Deutsch-Polnisch, de.pons.com (dostęp: 11 czerwca 2017 r.).

\section{Źródła internetowe}

Zapożyczenia językowe, https://pl.wikipedia.org/wiki/Zapożyczenia_językowe (dostęp: 8 czerwca 2017 r.).

Neologizmy $i$ ich rodzaje, słowniki-tematyczne/3663/neologizmy-i-ich-rodzaje/ (dostęp: 12 czerwca 2017 r.).

Dom pasywny, https:/encyklopedia.pwn.pl/haslo/dom-pasywny;3893602. html (dostęp: 4 czerwca 2017 r.).

\section{The aspects of translation of German neologisms from the end of the $20^{\text {th }}$ century into Polish}

Summary

The article presents the effects of research on the translation of German neologisms from the last decade of the $20^{\text {th }}$ century into Polish. The analysis included 42 dictio- 
nary entries which were divided into lexemes naming typically German phenomena. The second group proved to be more challenging to translate than the first group following the difficulties with accounting for stylistic features, particularly evaluative ones. The article critically discusses translation options found in German-Polish dictionaries and offers the author's own suggestions.

Keywords: borrowing, translation equivalents, contrastive linguistics

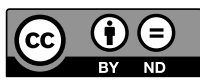

